\title{
PEMBERIAN KOMPRES KENTANG TERHADAP MASTITIS NON INFEKSI PADA IBU MENYUSUI
}

\section{RIRIS SITORUS ${ }^{1}$, GRACE ERLYN DAMAYANTI S², DIAH EVAWANNA ANUHGERA ${ }^{3}$, NIKMAH JALILAH RITONGA ${ }^{4}$, RAISHA OCTAVARINY ${ }^{5}$}

\author{
1,3,4FAKULTAS KEBIDANAN INKES MEDISTRA LUBUK PAKAM \\ ${ }^{2}$ FAKULTAS KEPERAWATAN DAN FISIOTERAPI INKES MEDISTRA LUBUK \\ PAKAM \\ ${ }^{5}$ FAKULTAS KESEHATAN MASYARAKAT INKES MEDISTRA LUBUK PAKAM \\ Jln. Sudirman No.38 Lubuk Pakam, Kabupaten Deli Serdang, \\ Sumatera Utara - Indonesia \\ e-mail : rizriris@gmail.com
}

\section{DOI $10.35451 / j k k . v 3 i 2.595$}

\begin{abstract}
Breastfeeding was an ideal way of feeding for the growth and development of the baby and affects the biological health for mother and baby. However, the breastfeeding process could be hampered due to problems, one of which was mastitis. Mastitis occured due to the narrowing of the lactiferous ducts in the breast and the mother may have flat, sunken or immersed nipples. So that the breasts become swollen, painful when pressed so that the mother feels breast discomfort. The impact of mastitis greatly affected the mother and baby's health. The mother would felt pain during breastfeeding so that she could experience high fever. Whereas in infants the need for breast milk was not optimal from the content of the milk. One of the efforts that could be done to overcome the occurrence of mastitis in nursing mothers was by applying a potato compress. This study aimed to determined the effect of potato compresses on non-infectious mastitis in nursing mothers. Pre-experiment (quasi-experimental) using the one group pre-test-post test technique was used as the research method. The population of this study were breastfeeding mothers with non-infectious mastitis with 10 people as sample with a purposive sampling technique. The results showed that using the Paired Sample T-Test analysis test obtained a p-value of $0.000<a=0.05$, it concluded that there was an effect of Potato Compress on Non-Infectious Mastitis in Breastfeeding Mothers. It is suggested that health workers provide information for breastfeeding mothers about potato compresses to treat noninfectious mastitis.
\end{abstract}

Keywords: Potato compress; non-infectious mastitis.

\section{Pendahuluan}

Bayi membutuhkan zat gizi yang tinggi untuk dapat mempertahankan kehidupannya. Kebutuhan ini dapat dicukupi jika bayi mendapatkan air susu ibu (ASI) secara eksklusif yaitu pemberian hanya ASI tanpa adanya pemberian cairan lain (Astuti, 2013). World Health Organization (WHO) telah merekomendasikan ASI eksklusif untuk diberikan kepada bayi hingga bayi 
berusia enam bulan (Tristanti \& Nasriyah, 2019).

Menyusui merupakan cara yang sangat ideal dalam pemberian makan untuk tumbuh kembang bayi serta mempengaruhi kesehatan biologis ibu dan bayi. Zat anti infeksi yang terdapat dalam komponen ASI dapat membantu melindungi bayi dari penyakit. Akan tetapi proses menyusui dapat terhambat karena adanya beberapa masalah. Mastitis merupakan penyebab yang sering terjadi. Mastitis merupakan bentuk inflamasi yang terjadi pada segmen payudara dengan atau tanpa adanya infeksi (Prihati \& Puspaningrum, 2018).

World Health Organization memperkirakan angka kejadian mastitis antara 2,6\%-33\%, prevalensi global kejadian mastitis sekitar $10 \%$ dari perempuan yang menyusui (Hanti, Handayani \& Saufi, 2018). Berdasarkan laporan dari Depertemen Kesehatan Indonesia berjumlah 876.665 orang, 38 persen wanita usia diatas 25 tahun tidak menyususi bayinya karena mastitis. Di Sumatera utara berkisar antara $40-60 \%$ wanita terdiagnostik mastitis. Berdasarkan data yang diperoleh dari penelitian di RB Mulia Kasih Bayolali pada bulan Januari hingga Desember 2011, jumlah ibu nifas 250 orang dengan data ibu nifas normal 180 orang $(72 \%)$, ibu nifas dengan mastitis 40 orang (16\%). Data yang didapatkan dari rekam medis RSUD Dr.Harjono Ponorogo tahun 2016 diperoleh 10 ibu nifas yang mengalami mastitis.

Mastitis terjadi karena terjadi penyempitan pada payudara di bagian duktus laktiferus dan bisa terjadi sang ibu memiliki putting susu yang datar, cekung atau pun terbenam. Sehingga payudara menjadi bengkak, nyeri saat ditekan sehingga ibu merasakan ketidaknyaman pada payudara. Mastitis Non-infeksi disebabkan oleh cara menyusui atau teknik yang tidak benar dikarenakan pemahaman ibu yang kurang mengenai teknik menyusui dan merawat payudara. $\mathrm{Hal}$ ini menyebabkan ibu merasa nyeri, bengkak dan tidak nyaman saat menyusui sehingga ASI tertahan di payudara.

Mastitis sangat mepengaruhi kondisi kesehatan ibu demikian juga bayi. Ibu dengan mastitis biasanya akan mengalami masalah untuk memberikan ASI kepada bayi (Hasanah, 2017). Ibu dengan mastitis akan mengalami nyeri pada saat pemberian ASI hingga dapat terjadi demam tinggi. Sedangkan pada bayi kebutuhan ASI yang didapatkan tidak optimal dari kandungan ASI tersebut, sehingga bayi akan mudah terserang penyakit karena kekebalan tubuh bayi yang kurang.

Salah satu upaya untuk mengatasi mastitis pada ibu menyusui adalah dengan melakukan kompres kentang. Kentang adalah jenis sayuran yang mudah ditemukan. Kentang banyak mengandung mineral natrium yang memiliki kadar alkalin yang tinggi sehingga dapat bermanfaat untuk melancarkan fungsi organ dan juga aman untuk dikonsumsi. Tidak ada efek samping yang dapat membahayakan ibu dan bayi dengan penggunaan kompres kentang (Lestari, 2014).

Penelitian sebelumnya yang dilakukan oleh Fafungkasari (2019) mendapatkan bahwa dengan memberikan kompres kentang (Solanum Tubernosum L.) dapat berpengaruh terhadap mastitis non infeksi pada ibu menyusui. Akan tetapi belum banyak evidence base yang menjelaskan bagaimana kompres kentang dapat berpengaruh pada mastitis non infeksi, sehingga perlu dilakukan penelitian untuk mengklarifikasi bagaimana pemberian kompres kentang memperngaruhi 
mastitis non infeksi pada ibu menyusui. Penelitian ini bertujuan untuk mengetahui pengaruh kompres kentang terhadap mastitis non infeksi pada ibu menyusui.

\section{METODE}

Penelitian ini menggunakan metode kuantitatif, dengan desain Pra Eksperiment (eksperimen semu) yang menggunakan teknik one group pre test- post test. Rancangan ini bertujuan untuk mengetahui adakah pengaruh pemberian kompres kentang terhadap mastitis pada ibu menyusui. Yang menjadi populasi adalah ibu menyusui dengan mastitis non infeksi dengan besar sampel sebanyak 10 orang dengan teknik purposive sampling. Observasi mastitis didasarkan pada jurnal Effects of Gua-Sha Therapy on Breast Engorgement: A Randomized Controlled Trial SBES (Subjective Breast 41 Engorgement Scale) dimana ada 3 pertanyaan untuk mengukur tingkat nyeri, bengkak dan ketidaknyaman serta diukur menggunakan VAS (visual analogue scale) dengan pemberian 0-10.

\section{HASIL}

Tabel 1. Distribusi Frekuensi Skala Nyeri Pada Ibu Menyusui dengan Mastitis Non Infeksi Sebelum dan Sesudah Diberikan Kompres Kentang

\begin{tabular}{lcc}
\hline \multicolumn{1}{c}{ Skala Nyeri } & $\mathrm{f}$ & $\%$ \\
\hline \multicolumn{1}{c}{ Sebelum } & & \\
\hline Nyeri Ringan & 2 & 20 \\
Nyeri Sedang & 8 & 80 \\
Nyeri Berat & 0 & 0 \\
\hline Total & 10 & 100.0 \\
\hline \multicolumn{1}{c}{ Sesudah } & & \\
\hline Nyeri Ringan & 8 & 80 \\
Nyeri Sedang & 2 & 20 \\
Nyeri Berat & 0 & 0 \\
\hline Total & 10 & 100.0 \\
\hline
\end{tabular}

Tabel 1 menunjukkan bahwa skala nyeri sebelum pemberian kompres kentang pada responden adalah nyeri sedang sebanyak $20 \%$ dan nyeri berat sebanyak $80 \%$. Sedangkan skala nyeri setelah pemberian didapatkan nyeri ringan sebanyak $80 \%$, dan nyeri sedang $20 \%$.

Tabel 2. Distribusi Frekuensi Skala Bengkak Pada Ibu Menyusui dengan Mastitis Non Infeksi Sebelum dan Sesudah Diberikan Kompres Kentang

\begin{tabular}{lcc}
\hline \multicolumn{1}{c}{ Skala Bengkak } & $\mathrm{f}$ & $\%$ \\
\hline \multicolumn{1}{c}{ Sebelum } & & \\
\hline Bengkak Ringan & 0 & 0 \\
Bengkak Sedang & 10 & 100 \\
Bengkak Berat & 0 & 0 \\
\hline Total & 10 & 100.0 \\
\hline \multicolumn{1}{c}{ Sesudah } & & \\
\hline Bengkak Ringan & 10 & 100 \\
Bengkak Sedang & 0 & 0 \\
Bengkak Berat & 0 & 0 \\
\hline Total & 10 & 100.0 \\
\hline
\end{tabular}

Dapat dilihat dari tabel 2 bahwa skala bengkak payudara responden sebelum diberikan kompres kentang adalah keseluruhannya dengan bengkak sedang dan sesudahnya keseluruhannya dengan bengkak ringan.

Tabel 3. Pengaruh Kompres Kentang Terhadap Mastitis Non Infeksi Pada Ibu Menyusui

\begin{tabular}{llllll}
\hline $\begin{array}{l}\text { Mastitis } \\
\text { Non } \\
\text { Infeksi }\end{array}$ & $\begin{array}{l}\text { Mea } \\
n\end{array}$ & SD & $\begin{array}{l}\text { Lowe } \\
r\end{array}$ & $\begin{array}{l}\text { Uppe } \\
r\end{array}$ & $\begin{array}{l}P \\
\text { Value }\end{array}$ \\
\hline $\begin{array}{l}\text { Skala } \\
\text { nyeri }\end{array}$ & 0,0 & 2,160 & 3,45 & 6,54 & 0,000 \\
Skala & 2,7 & 0,48 & 2,35 & 3,04 & 0,000 \\
Bengkak & 9 & 3 & & & \\
\hline \multicolumn{5}{c}{ Rata-rata skala nyeri sebelum } \\
dan sesudah kompres kentang pada ibu \\
menyusui adalah 5,00 dengan standar \\
deviasi 2,160. Nilai $p$ didapatkan 0,000 \\
(< 0,05) yang artinya terdapat \\
pengaruh kompres kentang terhadap
\end{tabular}


skala nyeri mastitis non infeksi pada ibu menyusui. Lebih lanjut didapatkan rerata skala bengkak sebelum dan sesudah pemberian kompres kentang adalah 2,79 dengan standar deviasi 0,483 . Nilai p didapatkan 0,000 (< $0,05)$ artinya kompres kentang memiliki pengaruh terhadap skala bengkak pada ibu menyusui. Maka dapat disimpulkan $\mathrm{HO}$ ditolak sehingga ada pengaruh kompres kentang terhadap mastitis non infeksi pada ibu menyusui.

\section{Pembahasan}

Penelitian mendapatkan bahwa terjadi perubahan skala nyeri payudara pada ibu menyusui sebelum dan sesudah pemberian kompres kentang. Sebelum diberikan kompres kentang mayoritas responden mengalami nyeri berat dan sesudahnya mayoritas responden mengalami nyeri ringan dengan perbedaan rerata skala nyeri adalah 5,00. Penelitian juga menunjukkan bahwa sebelum diberikan kompres kentang, keseluruhan responden mengalami bengkak sedang, dan setelah diberikan kompres kentang keseluruhan responden mengalami bengkak ringan dengan perbedaan rata-rata skala bengkak adalah 2,79.

$$
\text { Lebih lanjut penelitian }
$$

menunjukkan kompres kentang berpengaruh terhadap skala nyeri dan bengkak mastitis non infeksi pada ibu menyusui. Maka dapat disimpulkan bahwa kompres kentang memiliki pengaruh terhadap mastitis non infeksi pada ibu menyusui. Hasil penelitian ini didukung oleh temuan Fafungkasari (2019) yang mendapatkan bahwa pemberian kompres kentang (Solanum Tubernosum L.) berpengaruh terhadap mastitis non infeksi pada ibu menyusui.

Mastitis terjadi karena pada payudara terjadi penyempitan duktus laktiferus dan bisa terjadi sang ibu memiliki putting susu yang datar, cekung atau pun terbenam. Sehingga payudara menjadi bengkak, nyeri saat ditekan sehingga ibu merasakan ketidaknyaman pada payudaranya. Mastitis dapat berkembang menjadi abses payudara dan apabila tidak diatasi akan menjadi kanker payudara.

Kentang merupakan sayur yang mudah ditemukan. Selain itu kentang memiliki banyak kandungan mineral natrium dengan kadar alkalin yang tinggi. Kandungan kentang ini bermanfaat untuk melancarkan fungsi organ serta tidak menimbulkan efek samping yang berbahaya baik bagi ibu maupun bayi apabila dibandingkan dengan penggunaan kompres kol yang dapat mengiritasi payudara ibu (Lestari, 2014).

Kompres kentang dapat dilakukan atau diaplikasikan dengan cara mengiris tipis kentang sebanyak 6-8 iris dengan tipis kira-kira $1 \mathrm{~cm}$ dan direndam dan mangkuk yang berisi air selama 15-20 menit untuk mendapat efek yang dingin dan kanddungan kentang yang cocok pada peradangan dan nyeri serta bengkak,kemudian dilakukan kompres pada payudara yeng terkena mastitis selama 15-20 menit dan ulangi selama 3 kali dengan jeda istirahat 20-30 menit (Newman, 2019).

Kentang banyak mengandung mineral (potassium, magnesium, copper, kalsium, fosfor, zinc, dan zat besi). Kelompok mineral ini memiliki peran yang penting bagi tubuh dalam menjalankan fungsi organ dengan baik. Kentang juga memiliki zat antioksida. Asam fitrat yang terkandung dalam kentang bisa mengikat zat besi, pemicu kanker. Selain bagian isi, kulit kentang juga memiliki manfaat karena mengandung asam klorogenik berupa polifenol dapat berfungsi untuk menghambat terjadinya mutasi sel-sel yang mengakibatkan kanker.

Menurut peneliti, pemberian kompres kentang pada penelitian ini 
dapat memperlancarkan sirkulasi darah dan dapat mencegah sumbatan cairan susu sehingga mengatasi terjadinya mastitis.

\section{KESIMPULAN}

Dari hasil penelitian yang didapatkan maka disimpulkan bahwa terdapat pengaruh pemberian Kompres Kentang Terhadap Mastitis Non Infeksi Pada Ibu Menyusui.

\section{DAFTAR PUSTAKA}

Astuti, I. 2013. Determinan Pemberian ASI Eksklusif Pada Ibu Menyusui. Jurnal Health Quality

Fafungkasari, WTB. (2019). Pengaruh pemberian kompres kentang (Solanum Tuberosuk L.) terhadap mastitis non-infeksi pada ibu menyusui di Desa Wadang Ngasem Kabupaten Bojonegoro. Diunduh dari https://www.semanticscholar.org/pa per/PENGARUH-PEMBERIAN-

KOMPRES-KENTANG-(SOLANUM-L.)IBU-

Fafungkasari/c1cfb0d570d5f9761d3

8ecaadd09d3ec0bd5ab26 pada tanggal 21 Januari 2021.

Hanti, Handayani \& Saufi, 2018. Hubungan umur, pendidikan, pekerjaan, paritas dan riwayat mastitis dengan kejadian mastitis. Jurnal Kedokteran dan Kesehatan Indonesia (JKKI), Vol.9, No.3 (2018) Lestari, D., Zuraida, R., \& Larasati, T. (2014). Hubungan Tingkat Pengetahuan Ibu tentang Air Susu Ibu dan Pekerjaan Ibu dengan Pemberian ASI Eksklusif di Kelurahan Fajar Bulan. Medical Journal of Lampung University.

Prihati, Yuni \& Puspaningrum, Dewi. 2018. Asuhan kebidanan ibu nifas pada Ny. D, P1A0 hari ke 7 dengan mastitis di Puskesmas Donorojo, Kabupaten Jepara. Universitas Muhammadiyah Semarang. Diunduh dari http//repository.unimus.ac.id/2610/

1.3.ABSTRAK.pdf pada 20 September 2020

Tristanti, Ika \& Nasriyah. 2019. Mastitis (Literature Review). Jurnal ilmu keperawatan dan kebidanan. Vol. 10 No.2 (2019) 330-337. 